
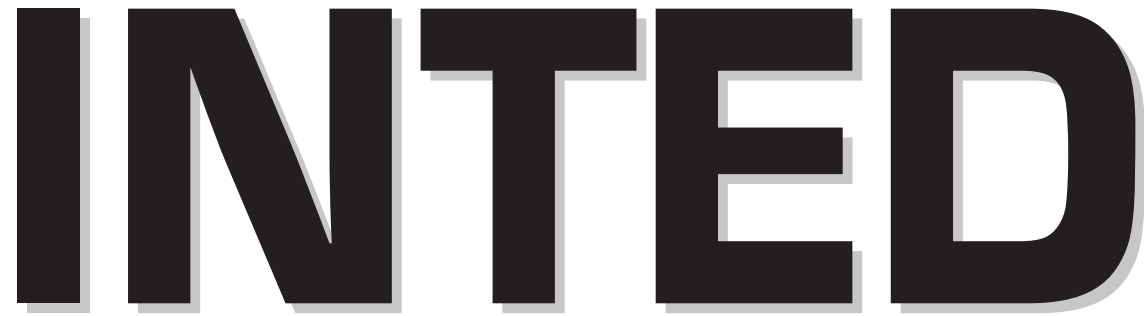

\section{7}

11th International

Technology, Education and

Development Conference

6-8 March, 2017

Valencia (Spain)

\section{CONFERENCE PROCEEDINGS}


Published by

IATED Academy

iated.org

INTED2017 Proceedings

11th International Technology, Education and Development Conference

March 6th-8th, 2017 - Valencia, Spain

\section{Edited by}

L. Gómez Chova, A. López Martínez, I. Candel Torres

IATED Academy

ISBN: 978-84-617-8491-2

ISSN: $2340-1079$

Depósito Legal: V-369-2017

Book cover designed by

J.L. Bernat

All rights reserved. Copyright (C) 2017, IATED

The papers published in these proceedings reflect the views only of the authors. The publisher cannot be held responsible for the validity or use of the information therein contained. 


\section{INTED2017 COMMITTEE AND ADVISORY BOARD}

\begin{tabular}{|c|}
\hline Adam Myers \\
\hline Agustín López \\
\hline Ali Ibrahim \\
\hline Altynbek Sharipbay \\
\hline Amparo Girós \\
\hline Ana Neves \\
\hline Ana Tomás \\
\hline Anja Docter \\
\hline Antonio García \\
\hline Asli Sungur Ergenoglu \\
\hline Brigit Kolen \\
\hline Ceyhan Cigdemoglu \\
\hline Chelo González \\
\hline Claire Fox \\
\hline Cláudia França \\
\hline Cristina Lozano \\
\hline Danielle Morin \\
\hline David Martí \\
\hline Diana Dias \\
\hline Diane Powles \\
\hline Diogo Casanova \\
\hline Dirk Verbeek \\
\hline Edita Butrime \\
\hline Eduardo Olguin \\
\hline Eduardo Penalosa \\
\hline Eladio Duque \\
\hline Elena Ors \\
\hline Elizabeth Romero \\
\hline Emmanuel Varouchas \\
\hline Eric Kuo-Hao Tang \\
\hline Fabiana Biasini \\
\hline Gabriela Kugler \\
\hline Giovanni Torrisi \\
\hline Helen Boulton \\
\hline Iain Weir \\
\hline Ignacio Ballester \\
\hline Ignacio Candel \\
\hline Iván Martínez \\
\hline James Sobredo \\
\hline James Sunney Quaicoe \\
\hline Javier Domenech \\
\hline Javier Martí \\
\hline Jim Playfoot \\
\hline Jin Feng \\
\hline Joanna Lees \\
\hline
\end{tabular}

UNITED STATES Jose F. Cabeza

SPAIN

SPAIN Jose Luis Bernat

UNITED ARAB EMIRATES José Luis Solleiro Rebolledo

KAZAKHSTAN Josephine Butler

SPAIN Kari Haavaag Voldsund

PORTUGAL Keith Buckley

SPAIN Kenneth Spiegel

NETHERLANDS Khondkar Islam

SPAIN Lenka Klimplová

TURKEY Li Jin

NETHERLANDS Lorena López

TURKEY Luis Gómez Chova

SPAIN Ma Jesús Suesta

UNITED KINGDOM Mangala Tawde

BRAZIL Margarida Romero

SPAIN Maria Porcel

CANADA Marian Stoltz-Loike

SPAIN Mark Sarvary

PORTUGAL Maurice Danaher

UNITED KINGDOM Mauro Figueiredo

UNITED KINGDOM Mónica Fernández

NETHERLANDS Nathalie Gettliffe

LITHUANIA Norma Barrachina

CHILE Olga Teruel

MEXICO Panagiotis Fotaris

SPAIN Patrick Fargier

SPAIN Patti Simone

UNITED STATES Paul Smith

GREECE Paulino Silva

TAIWAN Pavel Nastase

ITALY Peter Haber

GERMANY Ruth Kerr

BELGIUM Selma Koc

UNITED KINGDOM Serena St. Clair

UNITED KINGDOM Sergio Pérez

SPAIN Simon Cross

SPAIN Sirkku Männikkö Barbutiu

SPAIN Staffan Karp

UNITED STATES Stuart Shaw

ESTONIA Sune Weile

SPAIN Valentina Terzieva

SPAIN Valérie Lavergne Boudier

UNITED KINGDOM Victor Fester

UNITED STATES Wendy Gorton

FRANCE Xavier Lefranc
SPAIN

MEXICO

UNITED ARAB EMIRATES

NORWAY

UNITED STATES

UNITED STATES

UNITED STATES

SWEDEN

UNITED KINGDOM

SPAIN

SPAIN

SPAIN

UNITED STATES

CANADA

SPAIN

UNITED STATES

UNITED STATES

UNITED ARAB EMIRATES

PORTUGAL

SPAIN

FRANCE

SPAIN

SPAIN

UNITED KINGDOM

FRANCE

UNITED STATES

UNITED KINGDOM

PORTUGAL

ROMANIA

AUSTRIA

ITALY

UNITED STATES

UNITED STATES

SPAIN

UNITED KINGDOM

SWEDEN

SWEDEN

UNITED KINGDOM

DENMARK

BULGARIA

FRANCE

NEW ZEALAND

UNITED STATES

FRANCE 


\section{CONFERENCE SESSIONS}

\section{ORAL SESSIONS, 6th March 2017}

Educational Software Experiences

Social Media in Education (1)

Collaborative and Problem Based Learning (1)

Teachers Development: Online \& Blended Learning

Experiences in Math Education

Digital Competence for Lifelong Learning

ICT in Special Needs Education

Technology in Engineering Education

Videos for Learning

Blended Learning (1)

Collaborative and Problem Based Learning (2)

ICT Skills and Competencies among Teachers (1)

Technology in STEM Education

Quality Assurance \& Accreditation

Challenges of an Inclusive Classroom

Experiences in Engineering Education (1)

Preparing Pre-Service Teacher-Librarians for a Technological Environment

Learning Analytics and Adaptive Learning

e-Assessment

The other side of the Flipped Classroom

ICT Skills and Competencies among Teachers (2)

Experiences in STEM Education

International Experiences in Higher Education

New Trends in Humanities Education

Experiences in Architecture and Civil Engineering

Technology Enhanced Education to Adults and Seniors

Assessment of Student Learning

Student Support \& Tutoring

Pre-service Teacher Experiences

Teachers Experiences in STEM (1)

Work Integrated Learning \& Internship Programs

ICT Enhanced Language Learning

Experiences in Computer Science Education

\section{POSTER SESSIONS, 6th March 2017}

Emerging Technologies in Education

Pedagogical Innovations and New Educational Trends 


\section{ORAL SESSIONS, 7th March 2017}

Quality Assurance in e-Learning

Learning Management Systems \& Virtual Learning Environments

Serious and Educational Games

Competence Evaluation

Education and Globalization

Enhancing Learning and Academic Performance

Experiences in Primary \& Early Education

Pedagogical \& Didactical Innovations (1)

Experiences in Engineering Education (2)

e-Learning Experiences

MOOCs: Massive Open Online Courses

Virtual and International Collaboration

New Trends in Higher Education

Leadership \& University Management

University-Industry Collaboration

Teachers Experiences in STEM (2)

Pedagogical \& Didactical Innovations (2)

Flipped Learning (1)

Social Media in Education (2)

Learning Coding and its Applications

New Trends and Experiences in Lifelong Learning

Experiences in Multicultural Education

Entrepreneurship Education

Pedagogical Innovations in Foreign Languages

Experiences in Health Sciences Education

Flipped Learning (2)

Technological Issues in Education (1)

Games and Simulations Experiences

Lifelong and Adult Learning

Intercultural and Diversity Issues in Education

New Challenges for the Higher Education Area

Language Learning Innovations

Technology in Health Sciences Education

Blended Learning (2)

New Trends in MOOCs and Distance Learning

Technological Issues in Education (2)

Generic Skills and their Development

Experiences in Education for Disadvantaged Students

Employability Issues and Trends

New Challenges in Language Learning

Experiences in Business Education

\section{POSTER SESSIONS, 7th March 2017}

Experiences in Education

Global Issues in Education and Research 


\section{VIRTUAL SESSIONS}

Apps for education Augmented Reality Barriers to Learning

Blended Learning

Collaborative and Problem-based Learning

Competence Evaluation

Computer Supported Collaborative Work

Curriculum Design and Innovation

Digital divide and acces to internet

Diversity issues and women and minorities

E-content Management and Development

e-Learning

Education and Globalization

Education in a multicultural society

Educational Research Experiences

Educational Software and Serious Games

Enhancing learning and the undergraduate experience

Ethical issues in Education

Evaluation and Assessment of Student Learning

Experiences in STEM Education

Flipped Learning

Impact of Crisis on Education

Impact of Education on Development

Inclusive Learning

International Projects

Language Learning Innovations

Learning and Teaching Methodologies

Learning Experiences in Primary and Secondary School

Lifelong Learning

Links between Education and Research

Mobile learning

New projects and innovations

New Trends in the Higher Education Area

Organizational, legal and financial issues

Pedagogical \& Didactical Innovations

Pre-service teacher experiences

Quality assurance in Education

Research Methodologies

Research on Technology in Education

Student Support in Education

Technological Issues in Education

Technology-Enhanced Learning

Tutoring and Coaching

University-Industry Collaboration

Virtual Universities

Vocational Training 


\section{ABOUT INTED2017 Proceedings}

\section{HTML Interface: Navigating with the Web browser}

This USB Flash drive includes all presented papers at INTED2017 conference. It has been formatted similarly to the conference Web site in order to keep a familiar environment and to provide access to the papers trough your default Web browser (open the file named "INTED2017.html").

An Author Index, a Session Index, and the Technical Program are included in HTML format to aid you in finding conference papers. Using these HTML files as a starting point, you can access other useful information related to the conference.

The links in the Session List jump to the corresponding location in the Technical Program. The links in the Technical Program and the Author Index open the selected paper in a new window. These links are located on the titles of the papers and the Technical Program or Author Index window remains open.

\section{Full Text Search: Searching INTED2017 index file of cataloged PDFs}

If you have Adobe Acrobat Reader version 6 or later (www.adobe.com), you can perform a full-text search for terms found in INTED2017 proceedings papers.

Important: To search the PDF index, you must open Acrobat as a stand-alone application, not within your web browser, i.e. you should open directly the file "INTED2017.pdf" with your Adobe Acrobat or Acrobat Reader application.

This PDF file is attached to an Adobe PDF index that allows text search in all PDF papers by using the Acrobat search tool (not the same as the find tool). The full-text index is an alphabetized list of all the words used in the collection of conference papers. Searching an index is much faster than searching all the text in the documents.

To search the INTED2017 Proceedings index:

1. Open the Search PDF pane through the menu "Edit > Advanced Search" or click in the PDF bookmark titled "SEARCH PAPERS CONTENT".

2. The "INTED2017_index.pdx" should be the currently selected index in the Search window (if the index is not listed, click Add, locate the index file .pdx, and then click Open).

3. Type the search text, click Search button, and then proceed with your query.

For Acrobat 9 and later:

1. In the "Edit" menu, choose "Search". You may receive a message from Acrobat asking if it is safe to load the Catalog Index. Click "Load".

2. A new window will appear with search options. Enter your search terms and proceed with your search as usual.

For Acrobat 8:

1. Open the Search window, type the words you want to find, and then click Use Advanced Search Options (near the bottom of the window).

2. For Look In, choose Select Index.

3. In the Index Selection dialog box, select an index, if the one you want to search is available, or click Add and then locate and select the index to be searched, and click Open. Repeat as needed until all the indexes you want to search are selected.

4. Click OK to close the Index Selection dialog box, and then choose Currently Selected Indexes on the Look In pop-up menu.

5. Proceed with your search as usual, selecting other options you want to apply, and click Search.

For Acrobat 7 and earlier:

1. In the "Edit" menu, choose "Full Text Search".

2. A new window will appear with search options. Enter your search terms and proceed with your search as usual. 


\title{
COMPUTERISATION IN MANDATORY SCHOOLING IN MACEDONIA WITH AN ACCOUNT TO FOREIGN LANGUAGE TEACHING
}

\author{
Snezana Kirova, Tatjana Ulanska, Dragana Kuzmanovska, Biljana Ivanova \\ Faculty of Philology, University Goce Delcev (MACEDONIA)
}

\begin{abstract}
This paper reports on the outcome of a project 'Computer for Every Child' implemented in primary and secondary schools in Macedonia in 2007. The paper presents both foreign language teachers' and their primary and secondary school students' views, their personal judgement and evaluation of this project. It reports on a survey carried out on a number of primary and secondary school students' and their foreign language teachers. The paper aims at providing an insight into how teachers and students understand the implementation of ICT in the teaching process in the foreign language classroom, and it finally draws a few conclusions concerning corresponding changes necessary for the improvement of the teaching staff and the teacher training teaching process.
\end{abstract}

Keywords: ICT in education, foreign language teaching, ICT in foreign language education, outcomes.

\section{INTRODUCTION}

Education and the process of teaching have changed greatly over the last two decades. Information technologies, the computers, the Internet had inevitably imposed changes in the educational processes worldwide. The use of computers in education opened a new area of knowledge and imposed the use of new tools that changed some of the existing educational methods. This paper will report on a project named 'Computer for Every Child' implemented in primary and secondary schools in Macedonia in 2007. This project was successfully implemented in all state primary and secondary schools in Macedonia.

Following the contemporary and the newly accepted teaching methodology that includes ICT in the teaching processes, the Republic of Macedonia i.e. the Ministry of Education drafted a new national program for education in 2005. The project is based on the National Strategy for the Development of Education (2005-2015). This project is planned to provide 17,818 PCs, 98,710 LCD monitors, 98,710 keyboards, mice and 80,892 clients for primary and secondary schools in the Republic of Macedonia. These computers are to be used both as tools for teaching and as tools to access educational digital content on the global Internet network.

The project was being realized in three segments: Equipment purchase and installation; Maintenance, local and Internet connection of the equipment; and Development of digital content and teacher training for implementing instruction.

The project goal initially only for primary education was to improve and increase the use of ICT in all primary schools. The establishment of an effective and educational approach to the application of ICT is anticipated within the activities. The efforts of the country were not only focused on primary and secondary education but it further focused on the higher education institutions, encouraging the implementation of adapted new study programs that would follow the contemporary direction towards information societies. Therefore, the University for Information technology was founded. The reforms and the developments in the field of ICT, not only in the primary and secondary schools in Macedonia but also in the higher education institutions were made to produce qualified professional that would further improve the quality of life in the country.

\section{APPLICATION OF ICT IN THE FOREIGN LANGUAGE CLASSROOM}

The purpose of this paper was primarily found in our interest (as all authors of this paper have excessive foreign language teaching experience) to learn about the importance of the use of computers and ICT and how it is applied in the foreign language classrooms in the state schools in Macedonia. This paper will focus on the extent to which the foreign language teachers and their students recognize the use of ICT as an integral part in their foreign language classroom through personal views of both students and their teachers (primary and secondary). The shortcomings of the 
contemporary teaching process in the classrooms of foreign language in terms of successfully applying ICT with the reflection on the available resources will also be further discussed and presented. The issues that we wish to tackle here are students' and teachers' views and problems with ICT and to which extend it is used in the practices in the real classrooms.

The role of the teacher is still central in the educational process even though the techniques and methods have altered greatly over the years. The teachers are leaving the role of the only source of knowledge but take a new role of manager and facilitator in the teaching process. It is in our beliefs that the teachers are still the key to implement effective utilization of these resources in the teaching processes and in the educational system as a whole. As this project imposed the use of computers, teachers must have been successfully prepared to implement them in their classrooms. The introduction of computers and ICT in the schools included a training process for the teachers in the planning process of the implementation of this project. Further in this paper this training process will be discussed. Many researchers from this field agree that the teacher's knowledge of technology should be taken into account in the process of planning for technology use because teachers who participated in computer courses showed lower anxiety. Furthermore, that increased computer experience diminishes computer anxiety. Hence, the lack of computer knowledge inevitably imposes high anxiety and negative attitudes. It has been proved that teacher's attitudes toward the use of technology can be significantly improved with proper and intensive training.

\section{RESULTS OF THE SURVEY}

The research questions in the conducted interviews were constructed in a manner to value and estimate the participants' understandings of ICT and their place in the classrooms.

The survey included foreign language teachers from primary and secondary state schools in Stip, Macedonia. Both teachers and students received two questions and were asked to give an instant answer. The teachers were asked these two:

1 What is your personal experience regarding the use of the computers in your everyday teaching process? And

2 Can you name any improvements, changes, problems or issues in your personal teaching process since the implementation of computers in your classroom.

The questions were designed to provide us with an insight to the teachers' personal experiences with the use of computers in the foreign language classrooms. We have selected some of the answers of the teachers (given in prose style as we collected them) as an illustration of the conducted interviews:

It was not very difficult for me to change my old way of teaching; on the contrary, it helped me to explain some notions that are not familiar to my students: you know, because of cultural differences (secondary school English teacher);

My students know much more about computers than I do and often I find myself lost in the middle of the class if a technical problem occurs. When they do assignments on the computers I don't get the right feedback of their progress, sometimes they can copy things and I find it difficult to keep track of that. There are some good sides of course, but I often lose track of the process (secondary school English teacher);

The positive side of the use of computers lays in creativity and possibilities but the excessive use of computers in all their classes can be harmful for the students. Other problem is that they are quite old now and they are not maintained properly.

Some teachers provided one answer as a sum of the two questions. The answers collected by the teachers allowed us to conclude that all of the interviewed foreign language teachers use ICT in their classrooms. A number of teachers even claimed that the foreign language teachers use ICT much more that the other teachers from their schools due to the nature of the subject itself. Some claimed that the fact that they had no problems understanding English (some German teachers also claimed that language was no barrier to them either) made it much easier to them to apply ICT in their classroom in much greater extent than teachers teaching other subjects. Some teachers even claimed that they used ICT even before computers were implemented, by using their personal computers. There were answers where the teacher completely choses to rely on the materials and wishes to focus on the method of explicit explaining of the linguistic part of their subject. Many mentioned technical problems too, as well as the need of proper and better maintenance as many computers didn't work 
and it made a problem organizing the lesson. Teachers reported that lack of appropriate teacher training is the biggest problem as many of the teachers that work today in the schools in Macedonia received their teaching diplomas before computer education was even there. Even though teachers had a computer training program, they feel that is not sufficient.

The students were asked these two questions:

1 What is your personal experience regarding the use of the computers in your English/ German classes? And

2 Do you often use the computers in your classes and do you prefer a class when you use computers or a traditional class? The research questions are posed to investigate the effectiveness of the use of ICT in the foreign language classes. The students were asked to provide an instant answer on the spot in order to avoid the tendency among students to copy from each other. Here, again, we have selected some of the answers from the students:

a) yes, we use the computers in our classes of German quite often. Our teacher shows us things about German holidays, how they celebrate them... sometimes we do some exercises. I think I like it better when we use the computers in that class, but not always.

b) we don't use them much. Our teacher is not very good with computers, they are old, some are broken and if she has a problem she asks us for help and the whole lesson becomes a mess. It's ok as it is.

This selection of the students' answers showed a range of perspectives. From the answers of the students it was evident that they think the use of computers in class is most effective in the classes of foreign languages. The technical problems were also mentioned among their answers.

In terms of expected answers, we can refer to students seeing ICT as part of their classrooms and prefer its presence in their classes. The second question intentionally did not focus only on the foreign language classes in order to make a comparison between the foreign language teaching process to that or the other subjects.

As a summary of all answers of both teachers and students it can be concluded that there is a range of views, experiences and understandings of ICT.

\section{ANALYSIS AND DISCUSSION}

From the results gathered here it can be concluded that the use of computers, as a process to develop education in Macedonia, was in great extend successful in the teaching process of foreign language teaching. This is in great extent due to the nature of the subjects, the possibility to present and bring closer the culture of the target language that is taught and the lack of language barrier for the teachers.

As explained above, the introduction of computers and ICT in the schools in Macedonia included a training process for the teachers in the planning process of the implementation of this project. Still, we found out that this part of the implementation was not sufficient and has not given the anticipated results. We believe that further trainings to the effective exploitation of computers in the teaching process should continue for all involved teachers in the state schools in Macedonia. Teachers' lack of computer knowledge and skill was the main problem found while implementing computer use in teaching. Other problems we have encountered in our survey were the insufficient expertise, guidance and help in this process as well as insufficient technical assistance.

Computer technology has already become part of education in Macedonia and it is likely that education will continue to develop in that direction in the future. We believe that domestic researchers and scientists from the field should be encouraged to do research into this new area, study the impact of the actions that are taken and come to evaluations about the extent of the use of computers in teaching and learning, as well as the factors affecting the use of computers. In the process of preparing this paper we have come to an insight that it is very important to study the perceptions of the school teachers. As reported in the results, teachers that work today in the schools in Macedonia received their teaching diplomas before computer education and claim that a basic computer training course is far from sufficient. This imposes a different perspective that can be reviewed and examined by professionals from the teacher training colleges, whether this kind of reforms should have been done differently. 
The results that we received revealed that the foreign language teachers had more positive outcomes from the implementation of the computers that any other profiles of teachers.

And, finally, a similar survey can be made for the other subjects separately or the use of computers in the schools in Macedonia and in the entire educational process and also a study can be done in order to define certain educational technology standards for teachers and further develop plans how to reach those standards.

\section{REFERENCES}

[1] A. Hargreaves, Changing teachers, changing times, Trowbridge, Wiltshire, Redwood Books 1996.

[2] D. Lare, The key to technological innovation: The teacher. In J. Willis, B. Robin, \& D. A. Willis (Eds.), Technology and Teacher Education Annual, 1997.

[3] D. K. Larner \& L. M. Timberlake, Teachers with limited computer knowledge: Variables affecting use and hints to increase use, 1995.

[4] E. Downs, K. Clark \& J. Bennett, New directions for teacher education in the information age. In D.A. Willis, B. Robin \& J. Willis (Eds.), Proceedings of the Sixth International Conference of the Society for Information Technology and Teacher Education, International Conference 1995 (pp. 247-249). Chesapeake, VA: Association for the Advancement of Computing in Education (AACE), 1995.

[5] K. Lee, Enhanced learning environment for teachers: What next? In J. Willis, B. Robin, \& D. A. Willis (Eds.), Technology and Teacher Education Annual, 1997.

[6] M. McCannon, \& B. T. Crews, Assessing the technology training needs of elementary school teachers. Journal of Technology and Teacher Education, 2000.

[7] M. B. Troyer, Issues and problems in teacher computer literacy education. Journal of Research on Computing in Education, 1988.

[8] http://metamorphosis.org.mk/wp-content/uploads/2014/10/upotreba-na-kompjuterite-voobrazovanieto.pdf Retrieved on 12/29/2016 1:41 PM

[9] http://vlada.mk/proekti/kompjuter-za-sekoe-dete Retrieved on 12/29/2016 1:50 PM 